\title{
CONTAMINACIÓN DE ARROYOS EN EL VALLE DE PUNILLA (CÓRDOBA- ARGENTINA). APLICACIÓN DE LA LEY DE RESIDUOS PELIGROSOS 24051
}

\author{
PUNILLA WAYQ'UPI YARQA CH'ARKUY (CORDOBA-ARGENTINA \\ SUYUPI). KAMACHIKUN LEY DE RESIDUOS PELIGROSOS NISQA \\ 24051
}
POLLUTION IN STREAMS AT PUNILLA VALLEY
(CÓRDOBA-ARGENTINA). THE ENFORCEMENT OF
HAZARDOUS RESIDUES LAW 24051

\author{
Fernando Martín Bertone ${ }^{(1)}$ \\ Analía Verónica Gallaratto(2)
}

Ch'uyanchakuy: Huk huchuy mayu purin Valle de Punilla aska qoñi wayqo ayllunkunapi, provincia de Cordobapi, Hatun Suyu Argentinapi, chay hatun yakuqa chayan San Roque qochaman, Chay qochamantan yakuta ukyanku Cordoba ayllupi, Chay llaqtapi iskay kuno runa tiyanku, Chay yakuqa qanrachasqa kan imaymana qanrayakuwan llaqtamanta chayasqanwan rayku. Chay raykun, aplicacun Ley Nacional de Residuos Peligrosos 24051, Codigo Penaltawan, chayta ruawanku Ilaqtaq qanrachasqanku yakunta rayku. Hinaspañataqmi rimakun pachamamanchista qellichisqanku llegislaciunta.

Yuyaysapa simichakuna: Huch'uy mayukuna, Punillabamba, Qhellichay, Ch'ikina q'opa, Qelqa kamachi.

Resumen: Un arroyo que transita por el Valle de Punilla (Córdoba, Argentina), perteneciente a la cuenca hídrica que desemboca en el Lago San Roque -reservorio natural que suministra agua potable a la ciudad de Córdoba, con más de dos millones de habitantes- fue contaminado por descargas de desagües cloacales,

(1) Abogado. Profesor de la Universidad Nacional de Córdoba, Facultad de Derecho y Cs. Sociales. bertonemartin@hotmail.com

(2) Abogada egresada de la Universidad Nacional de Córdoba, Facultad de Derecho y Cs. Sociales analiagallaratto@hotmail.com 
proveniente de fallas en la estación de bombeo de la empresa de servicio público de tratamiento de los residuos. Se efectuaron análisis químicos al curso de agua, que determinaron la presencia de bacterias contaminantes, por lo que se aplicó la Ley Nacional de Residuos Peligrosos 24051 y el Código Penal Argentino, por tratarse de un daño calificado a un bien de uso público. Este artículo describe la aplicación y la efectividad empírica de la legislación aplicable en materia de contaminación ambiental.

Palabras clave: Arroyos, Valle de Punilla, Contaminación, Residuos peligrosos, Ley, Líquidos cloacales

Abstract: A stream that passes through the Punilla Valley (Córdoba, Argentina), belonging to the water basin that flows into the San Roque Lake -a natural reservoir that supplies drinking water to the city of Córdoba, with more than two million inhabitants- was contaminated by discharges of sewage drains, coming from failures in the pumping station of the waste treatment company. Chemical analyzes were carried out on the water course, which determined the presence of contaminating bacteria, then the National Hazardous Waste Law 24051 and the Argentine Penal Code were applied, as it is a damage to a good for public use. This article describes the application, and empirical effectiveness, of the legislation on environmental pollution.

Keywords: Streams, Punilla Valley, Pollution, Hazardous waste, Law, Sewage 


\section{El sistema jurídico vigente}

En este artículo se responderá a los interrogantes consistentes en cómo gestionar desde el Derecho y los sistemas democráticos los conflictos relacionados a la degradación del medio ambiente, las disputas relacionadas al recurso natural del agua.

En el sistema de derecho argentino, se parte de una pirámide jurídica cuya cúspide es la Constitución Nacional, la cual en su Art. 41 reza:

"Todos los habitantes gozan del derecho a un ambiente sano, equilibrado, apto para el desarrollo humano y para que las actividades productivas satisfagan las necesidades presentes sin comprometer las de las generaciones futuras; y tienen el deber de preservarlo. El daño ambiental generará prioritariamente la obligación de recomponer, según lo establezca la ley".

El bien jurídico protegido es la calidad de vida humana. De modo que en nombre de cierta calidad de vida humana no podría convalidarse (ni ética, ni jurídicamente) el perjuicio al equilibrio medioambiental ni el menoscabo a la diversidad biológica. Asimismo, se ordena a las autoridades que provean a la protección del derecho al medio ambiente sano y equilibrado, como así también a la utilización racional de los recursos naturales, el cual tiene reconocimiento internacional en la Declaración de Estocolmo, aprobada por la ONU en 1972.

Con respecto al rol del Estado, éste debe generar un adecuado sistema de premios y castigos con relación al "comportamiento ambiental", una estructura de control capacitada que articule las instancias de prevención y sanción en las diferentes jurisdicciones que integran un Estado Federal, una interpretación uniforme de la "obligación prioritaria de recomponer", constitucionalmente consagrada en el artículo 43 de la Constitución Nacional, en caso de daño ambiental y la concientización que se debe proteger el medio ambiente en base a argumentos extraeconómicos. (Conf. Rosatti, Horacio, 2011,488 y ss.).

En la situación actual de los arroyos de la provincia de Córdoba, Argentina, es moneda corriente el derramamiento de residuos que afectan la calidad del agua, recurso natural escaso y de invaluable importancia, comprometiendo seriamente a las generaciones futuras, aunque resulta difícil su aceptación o percepción como tal por los involucrados.

El abordaje que utilizamos es, por un lado, la legislación de derecho general donde, además de la Constitución Nacional y los tratados internacionales, ya citados ut supra, la Provincia de Córdoba se encuentra regulada por: 
1) La Constitución Provincial. Arts. 11, 38 inc. 8, 53, 58, 66, 68, 110 incs. $15,19,38$ y 186 inc. 7. Otorga suma importancia al cuidado del medio ambiente, dedicándole especial atención. Esto está contemplado en las Declaraciones de fe política, y considerado dentro de los derechos sociales y deberes. Garantiza su protección tanto por la ley como por el Estado, estando contenido dentro de las Políticas especiales.

2) Ley Provincial del Ambiente No 7343/85. Cuyo título completo es "Principios Rectores para la Preservación, Conservación, Defensa y Mejoramiento del Ambiente" y su posterior Decreto Reglamentario № 2131/00. Este Decreto reglamenta la Ley en lo referente a Evaluación de Impacto Ambiental, derogando el anterior Decreto № 3290/90. A los efectos de esta Ley, la preservación, conservación, defensa y mejoramiento del ambiente comprende, entre otros aspectos considerados, el ordenamiento territorial y la planificación de los procesos de urbanización poblamiento, industrialización, explotación minera y expansión de fronteras productivas en función de los valores del ambiente, así como la utilización racional del suelo, agua, flora, fauna, gea, paisaje, fuentes energéticas y demás recursos naturales en función de los valores del ambiente. Esta Ley estipula que deberán regularse las acciones, actividades u obras públicas y privadas, que, por contaminar el ambiente con sólidos, líquidos, gases y otros materiales residuales y/o ruido, calor y demás desechos energéticos, lo degraden en forma irreversible, corregible o incipiente y/o afecten directa o indirectamente la salud de la población. En su Artículo 52 inciso g, se indican como actividades degradantes o susceptibles de degradar el ambiente, entre otras, las que emitan directa o indirectamente ruidos. En su Capítulo I, De las aguas, los suelos y la atmósfera, Sección I, De las aguas, los suelos y la atmósfera en sentido amplio, Artículo 8, establece que: "Todas las personas cuyas acciones, actividades y obras degraden o sean susceptibles de degradar en forma irreversible, corregible o incipiente el suelo, las aguas, la atmósfera y sus elementos constitutivos, quedan obligados a instrumentar todas las medidas necesarias para evitar dicha degradación".

3) Decreto Provincial № 5589/73. También conocido como "Código de Aguas de la Provincia de Córdoba". Fija como Autoridad de Aplicación a la actual Secretaría de Recursos Hídricos, lo cual significa que dicho Organismo posee, entre otras facultades, el poder de policía en materia de contralor de vertidos de aguas residuales a cursos de agua provincial, superficial y/o subterráneos, y es el encargado de autorizar las descargas, prohibir o clausurar las mismas, aplicar multas, entre otras.

4) Decreto Provincial № 415/99. Denominado“Normas Provinciales para la Protección de los Recursos Hídricos Superficiales y Subterráneos"y su modificatorio $N^{\circ} 2711 / 01$. Se aplica a todas las actividades industriales, comerciales y de servicios cuyos residuos sean o vayan a ser vertidos a cuerpos receptores finales (ríos, embalses, arroyos, canales de desagües, colectores pluviales, pozos o perforaciones 
absorbentes, sistemas de riego, etc.). Se debe contar con la Autorización de descarga de líquidos residuales otorgada por la Dirección Provincial de Agua y Saneamiento (actualmente Secretaría de Recursos Hídricos). Los Organismos Municipales o Comunales que posean normativa propia pueden hacer cumplir la misma dentro de su jurisdicción, siempre que ésta sea de carácter igual o más restrictiva que la Provincial.

5) Resolución 233/2007. De la ex DIPAS (hoy Secretaría de Recursos Hídricos y Coordinación, del Ministerio de Agua Ambiente y Servicios Públicos de la Provincia de Córdoba). Estipula que todo emprendimiento que pretenda instalarse en jurisdicción de cualquier Municipio o Comuna de la Provincia de Córdoba, y que por su naturaleza pueda producir un efluente residual (cloacal o industrial), y cuyo vertido se prevea efectuar en cursos de aguas superficiales y/o subterráneos, lagunas, lagos, embalses, y en toda aquella que pertenezca al dominio público provincial, deberá presentar ante el Municipio o Comuna, como requisito indispensable para su habilitación, la autorización precaria correspondiente para la evacuación de los líquidos residuales emanada por ese Organismo Provincial,

6) Resolución 111/14. A través de la cual se instrumenta la "Norma para la Presentación y Diseño de Sistemas y Obras Hidráulicas en la Provincia de Córdoba". Dicha norma está destinada a establecer una guía para la ejecución de proyectos de sistemas y obras hidráulicas dentro del ámbito territorial de la Provincia de Córdoba. Se pretende uniformizar las presentaciones para una fácil comprensión de las memorias técnicas, descriptivas, pliegos, cómputos, análisis de precios, presupuestos y planos.

Por otro lado, desde el punto de vista de la legislación de Derecho Penal, contamos con el Código Penal Argentino, arts. 200, 201 y 202 y la Ley Nacional de Residuos Peligrosos № 24051/21, donde el art. 55 prevé tres conductas típicas que se relacionan con tres objetos sobre los cuales recae la acción. Las acciones reprimidas son adulterar, envenenar o contaminar, y uno de los objetos sobre los cuales recae es el agua. "Adultera" el que altera las sustancias de esas materias agregándoles otras, o logrando su corrupción mediante otro proceso, concepto dentro del cual queda subsumido el de contaminación. El sólo adulterar no configura ese delito, es menester la presencia de riesgo. Se trata de un delito de peligro que amplía notablemente la punibilidad del art. 200 del Código Penal, y que la acción punible encuadra en el concepto de contaminación del medio ambiente de un modo peligroso para la salud. (Conf. CAFFERATTA, Néstor, 2012, 989 y ss.).

\section{El caso}

En esta parte se analiza el hecho ocurrido entre el primero de abril del dos mil diecisiete y el diecisiete de agosto de dos mil diecisiete, en el cual dos coimputados quienes se desempeñan, el primero de ellos como coordinador 
operativo, responsable de la operación y mantenimiento integral del servicio de conexiones domiciliarias, redes colectoras y conducciones primarias, estaciones de bombeo, plantas depuradoras de efluentes y la disposición final de los efluentes cloacales de una empresa dedicada al tratamiento de líquidos cloacales, y el segundo responsable actuaba como coordinador general del área comercial y financiera de la misma empresa.

Ambos, en forma dolosa habrían omitido efectuar las tareas esenciales de mantenimiento y reparación necesarias en la Estación de Bombeo ubicada sobre la Ruta № 38 de la Localidad de Huerta Grande de la provincia de Córdoba-Argentina, ocasionando con dicha inacción, que las bombas fallaran y dejasen de funcionar correctamente, Esto incrementó el riesgo no permitido, por lo que los efluentes cloacales ingresados a dicha Estación resultasen volcados al Arroyo Huerta Grande de la cuenca hídrica que desemboca en el Lago San Roque, que es el reservorio de agua del que se toma el líquido elemento para suministrar, luego de su tratamiento, agua potable a la ciudad de Córdoba, con más de dos millones de habitantes.

Dicho arroyo está ubicado a cien metros de la mencionada estación de bombeo, sin recibir el correcto tratamiento de purificación, estando tales residuos peligrosos arrojados (bacterias coliformes totales y fecales en un valor estimativo de 16.000) por encima de los niveles máximos permitidos para su vertido (Decreto Provincial 415/99), mientras que aguas arriba de dicho volcamiento, aquellos valores eran normales según legislación antes referenciada (valor estimativo de 2400 de bacterias coliformes totales y 64 fecales), atento a los análisis efectuados por la Sección de Química Legal de Policía Judicial y de laboratorio de química aplicada de la Universidad Tecnológica Nacional. Que a consecuencia de ello el curso de agua que fluye del referido arroyo, resultó contaminada de un modo peligroso para la salud de las personas expuestas a la misma, provocando un daño intencional al mismo bien de uso público.

\section{La investigación}

La problemática planteada fue instada por tres partes, siendo en primer lugar por el Intendente del Municipio afectado, por un grupo de vecinos y también por la prensa. Todos los nombrados dieron conocimiento a la justicia provincial competente, sobre el volcamiento de líquidos cloacales sin el tratamiento adecuado sobre un arroyo que transita por varias comunidades del interior provincial, perteneciente a la cuenca San Roque, debido a la falta de las previsiones correspondiente por parte de la empresa prestataria del servicio público encargado del tratamiento de dichos líquidos contaminantes.

Los vecinos afectados aportaron documentación que acreditaron sus reclamos, consistentes en actas elaboradas por las municipalidades afectadas, denuncias a los medios de comunicación, actas provenientes de los organismos 
de control provincial, dependientes del Ministerio de Ambiente, siendo tales la Dirección de Policía Ambiental dependiente del Ministerio de Agua, Ambiente y Servicio Publico del Gobierno de la Provincia de Córdoba, y el Ente Regulador de Servicios Públicos -ERSEP-, como así también muestras fotográficas, videos con reproducciones de la contaminación, relevamiento de la Defensoría del Pueblo de la provincia. Estos documentos dan cuenta del derramamiento y de la falta de control y previsión de sus responsables: los integrantes de la empresa prestataria del servicio de tratamiento de los líquidos cloacales.

Por su parte, como respuesta al reclamo, la empresa prestataria del servicio público mentado, a su vez, realiza su descargo poniendo de manifiesto de que supuestamente fueron víctimas de hechos de vandalismo en las bombas ubicadas en ese lugar, las cuales, al dejar de funcionar colapsaron la red y produjeron los volcamientos contaminantes, y que tantas eran las veces que se rompían que no podían reponerlas.

Planteadas de esta forma ambas posiciones, la justicia constató objetivamente que sí se producían los volcamientos aludidos, constituyéndose en el lugar personal especializado de la sección de Química Legal dependiente de la policía científica, quien recolectó varias muestras de líquidos existentes en una alcantarilla con tapa circular metálica al nivel del suelo, de la cual fluía un líquido oscuro con olor nauseabundo que corría hasta verterse en el arroyo; también recolectó líquido fluvial, que a unos 5 metros río arriba recibe el mencionado líquido oscuro con olor nauseabundo, y por último, tomó otras muestras de líquido fluvial a unos 50 metros, río abajo, del mencionado punto de confluencia.

Así las cosas, rápidamente se solicitó la Cooperación Técnica de Policía Judicial de la Provincia de Córdoba, a escaso tiempo de los volcamientos, siendo las secciones de Química Legal, Fotografía Legal y Planimetría, donde peritos idóneos, de profesión bioquímicos extrajeron tres muestras de líquidos para analizar: 1) En el lugar del volcamiento, 2) Río arriba de la descarga y 3) Río abajo, luego de la descarga.

Seguidamente, y de acuerdo a los protocolos de preservación de las muestras obtenidas, las mismas fueron trasladadas hacia el Centro de Investigación y Transferencia en ingeniería química ambiental (CIQA), organismo que nace como consecuencia de compromiso social asumido por el Departamento de Ingeniería Química de la UTN, Facultad Regional Córdoba, a fines de la década del 90. El equipo está conformado por profesores e ingenieros quienes asumieron la misión de lograr establecer vínculos Universidad - Empresa; apoyando la capacitación profesional, generando conocimientos, aplicando el conocimiento a la producción, al desarrollo y distribución de los bienes y servicios, promoviendo el uso en forma sostenible de los recursos y respetando el medio ambiente, transfiriendo tecnología, promoviendo el desarrollo de las economías regionales y nacionales. 
Este organismo, usando como patrón objetivable de medición la legislación vigente, siendo el Decreto Provincial 847/16-Anexo I- "Estándares biológicos y orgánicos de calidad para vertido de los efluentes líquidos", determinó que en la muestra 1) donde se produjo el volcamiento, se observó la presencia de bacterias coliformes totales, bacterias coliformes fecales y escherichia coli termoestable en un valor estimativo de 16.000 por NMP/100 ml, por encima de los niveles permitidos para su vertido admitidos cuando se trata de descarga a cursos de agua superficiales según la legislación, mientras que en la muestra 2) río arriba aquellos valores eran normales según legislación antes referenciada (valor estimativo de 2400 por NMP/100 ml de bacterias coliformes totales y 64 de fecales y de escherichia coli termoestable), y en 3) río abajo se mantiene el valor de 16.000 por NMP/100 ml para bacterias coliformes totales, y 200 por NMP/100 ml de bacterias fecales y de Escherichia coli termoestable.

Asimismo, luego de la primera denuncia, hubo un nuevo volcamiento de líquidos cloacales, por lo se efectuó una nueva recolección de muestras sobre el mismo arroyo, arrojando en la descarga nuevamente números alarmantes, según los resultados obtenidos por el Centro de Investigación y Transferencia en Ingeniería Química Ambiental (CIQA). Consta que luego de estar en contacto con los líquidos cloacales, el arroyo contenía bacterias coliformes totales tenían un valor de 22.000 por NMP/100 ml, fecales en 1.700 por NMP/100 ml y escherichia coli termoestable en un valor estimativo de 400 por NMP/100 ml), mientras que río arriba aquellos valores eran sensiblemente inferiores (valor estimativo de 1700 de bacterias coliformes totales, 11 de fecales y apenas 7 de escherichia coli termoestable).

Continuando con la investigación del hecho, se efectuaron numerosos allanamientos a la empresa prestataria del servicio público, en su casa central en la ciudad de Carlos Paz y sus sedes de Huerta Grande y La Falda, donde se secuestró documentación importante para la causa, siendo tales numerosas actas de constatación de infracciones advertidas por parte de los organismos provinciales de control como así también, el Estatuto Constitutivo de la empresa, su concesión con la Provincia de Córdoba y el organigrama funcional donde se logró determinar la participación de los responsables de la empresa concesionaria del tratamiento de líquidos cloacales de la zona afectada. Así se desprende que uno de sus responsables se desempeña como coordinador operativo, encargado de la operación y mantenimiento integral del servicio de conexiones domiciliarias, redes colectoras y conducciones primarias, estaciones de bombeo, plantas depuradoras de efluentes y la disposición final de los efluentes cloacales, y el segundo responsable de la contaminación, es el coordinador general del área comercial y financiera de la misma empresa, habiendo asumido en sus respectivas contrataciones la obligación legal del mantenimiento y tratamiento de los líquidos cloacales, fijándose un plazo determinado para efectuar las reparaciones que fueran necesarias y habiendo asumido por ello ambos imputados nombrados la posición de garantes por función de vigilancia de fuentes de peligro, toda vez que la actividad por ellos desarrollada 
consistía en un servicio público esencial (sanitario), “(...) se considerará a quien es garante porque se encuentran en posición de evitar que se concreten los daños para el bien jurídico que proceden de... fuentes de peligro o de otras personas que debe supervisar o controlar, se trata de una función de control o vigilancia que le impone deberes..." (Conf. DE LA RUA-TARDITTI,2014,355 y ss.). Asimismo, se constata por la justicia que el cese del correcto funcionamiento de la estación de bombeo se debió al deterioro de las unidades debido a la omisión de sus reparaciones por parte de sus responsables; lo que es acreditado por la autoridad de aplicación, siendo el Ente Regulador de Servicios Públicos (ERSEP), donde en acta de constatación revela que se contaba con tres bombas, de las cuales ninguna funcionaba, una de ellas desde aproximadamente sesenta y cinco días, otra treinta días y la última desde hace una semana, observándose el derrame que sale por la boca del registro, cuyo vertido cae sobre el arroyo colindante, en dicha acta, uno de los responsables estimó tener una bomba nuevamente funcionando en dos días, lo que no ocurrió.

A posteriori, la empresa prestataria informó que este evento fue producido por actos de vandalismos, sin embargo, ERSEP efectúa un informe técnico donde manifiesta que del estudio de los antecedentes surge que el bombeo estuvo fuera de funcionamiento cinco días corridos en los cuales la Concesionaria ha vertido de manera directa los efluentes, que la única medida de mitigación tomada por la Concesionaria fue la de clorar el efluente en horario diurno, alegando vandalismo por la noche.

De los actuados en el proceso, en relación al "caso fortuito", no puede considerarse como tal toda vez que la primera bomba falló sesenta y cinco días y la segunda treinta días previo al evento, pudiéndose disponer de una bomba alternativa, colocada de manera temporaria, a fin de evitar dejar sin reserva la estación de bombeo. Esto se ve reflejado en la nota explicativa de la reparación donde aparte de reparar y volver a instalar la bomba que había fallado, también se sumó una segunda bomba al sistema. Cabe destacar que todo sistema de bombeo debe contar por norma con un respaldo que es función de la cantidad de bombas necesarias para el mismo. En este caso debiera haber instalada como mínimo una bomba en reserva.

\section{La imputación jurídica penal}

En virtud de la prueba recolectada, se imputó e indagó a sus responsables por los delitos de contaminación ambiental dolosa continuada previsto en el art. 55 de la Ley Nacional Argentina de Residuos Peligrosos 24051, por cuanto se encuentra acreditada la concurrencia de los tres requisitos de tipicidad exigidos por dicha figura penal: a) Utilización de alguno de los residuos peligrosos; b) Contaminación de uno de los objetos de protección (agua); y c) Contaminación de modo peligroso para la salud de las personas. 
En relación a la primera de las exigencias señaladas, el art. $2^{\circ}$ de la referida ley establece:

"Será considerado peligroso, a los efectos de esta ley, todo residuo que pueda causar daño, directa o indirectamente, a seres vivos o contaminar, el agua, la atmósfera o el ambiente en general. En particular serán considerados peligrosos los residuos indicados en el anexo II de esta ley".

Si bien los efluentes cloacales no se encuentran mencionados entre los residuos descriptos en el listado del Anexo I de la Ley 24.051, los mismos reúnen dos de las características descriptas en el Anexo II de la referida normativa nacional: H6.2 "Sustancias infecciosas": sustancias o desechos que contienen microrganismos viables o sus toxinas, agentes conocidos o supuestos de enfermedades en los animales o en el hombre; y H12 Ecotóxicos: sustancias o desechos que, si se liberan, tienen o pueden tener efectos adversos inmediatos o retardados en el medio ambiente debido a la bioacumulación o los efectos tóxicos en los sistemas bióticos. ${ }^{(3)}$

Respecto al segundo de los requisitos, de las conclusiones de la pericia química-microbiológica practicada sobre los efluentes arrojados desde la Estación de Bombeo, surge que el arroyo resultó contaminado, ya que se determinó que ambas muestras de agua tomada de este último (río abajo), la presencia de 16000 mil bacterias coliformes totales por NMP/100 ml. en el primer caso y 22000 mil bacterias coliformes totales por NMP/100 ml en el segundo, como así también, aumentó Ilamativamente la cantidad de bacterias coliformes fecales y de Escherichia coli termoestable. Lo permitido es muy inferior a los resultados encontrados.

En cuanto al tercero de los requisitos exigidos por la aludida ley ambiental: "contaminación de un modo peligroso para la salud", cabe destacar que el tipo penal en análisis se trata de un delito de peligro abstracto o hipotético, el cual no requiere para su consumación la concreción de un resultado lesivo,

(3) Amén de ello, cabe destacar que las enumeraciones contenidas en los anexos I y II deben considerarse no taxativas sino enumerativas (TSJ, Sent. 421 del 17/09/2015 "Gabrielli, Jorge Alberto y otros p.ss.aa infracción Ley 24.051 -Recurso de Casación-SAC 2403217-, y Cámara Federal de San Martín en el precedente "Wentzel", compartido por Mahiques, Leyes Penales Especiales, Tomo I, pág. 282/283). 
sino que basta que exista la posibilidad de que con la conducta de contaminar se pueda poner en riesgo la salud de las personas. Tal criterio es avalado por la jurisprudencia del Tribunal Superior de Justicia de la provincia de Córdoba ${ }^{(4)}$.

Todo ello, produjo un daño al Arroyo, el que se califica al tratarse de un bien de uso público de toda la comunidad de las localidades afectadas, por lo que la conducta de sus responsables encuadra en los delitos de daño calificado a un bien de uso público y contaminación dolosa continuada en concurso ideal (arts. 45, 54, 184 inc. $5^{\circ}$ del Código Penal argentino, art. 55 de la ley de Residuos Peligrosos 24051 y 55 "a contrario sensu" del Código Penal Argentino) y desobediencia a la autoridad reiterada -cuatro hechos- (arts. 55 y 239 del Código Penal Argentino), todo en concurso real (art. 55 del Código Penal Argentino).

Asimismo, teniendo en cuenta que dentro de los fines de la investigación penal preparatoria (Art. 302 del Código Procesal Penal de la Provincia de Córdoba) se debe impedir que el delito cometido produzca consecuencias ulteriores, y en sintonía a la reconocida doctrina que así lo expresa: "(...) durante la investigación preparatoria se deberá impedir que el delito en cuestión produzca consecuencias ulteriores a ella, esto es, deberá... procurarse que cese la continuidad o permanencia en esta clase de delitos... o que no permanezcan las consecuencias del delito... etcétera". Es más, el comentario transcripto expresa: "(...) se autoriza al tribunal a ordenar de oficio o a pedido del Ministerio Público o del actor civil otras medidas cautelares (...)" (CAFFERATA, TARDITTI, 2003. págs. 7 y ss.).

(4)

en los fallos ya citados, y por la Corte Suprema de Justicia de la Nación Argentina, en los autos caratulados: "Montenegro, Jorge Celso s/ denuncia Contaminación Ambiental" de fecha 20/05/2003 y "Zardi, Alejandro W. s/ denuncia infracción ley 24.051" resuelta el 8 de agosto de 2002, y por los siguientes autores: Mahiques, Carlos, Leyes penales especiales, Ed. Fabián J. Di Plácido, 2004, tomo I, pág. 284; Mandelli, Adriana Ley de Residuos Peligrosos en Estudios de figuras delictivas, tomo II-B, pág. 222; Reinaldi, Víctor Félix, Manual de Derecho Penal; Ricardo Núñez, Parte Especial, 2da. edición actualizada, Lerner, Córdoba, 2000, tomo II, pág. 184. En el mismo sentido se ha pronunciado el Tribunal Superior de Justicia de Córdoba en los autos caratulados "Gabrielli Jorge Alberto, Pancello Edgardo Jorge, Parra Francisco Rafael p.ss.aa. Infracción Ley № 24051-Recurso de Casación-" (Sentencia № 421 de fecha 17-92015); la Cámara Federal de San Martín en autos "Constantini, Rodolfo y otros s/averiguación contaminación en Río Reconquista", y la Cámara Federal de General Roca (Rio Negro) en la causa "Peláez"-- Que en el caso de marras, tal posibilidad de riesgo existió, por cuanto la pericia química-microbiológica estableció que las bacterias coliformes totales, fecales y de Escherichia coli termoestable, extremadamente superior al prescripto por el Decreto 847/16 de la Provincia de Córdoba. Dicha situación trae como consecuencia que los cuerpos de agua del arroyo se contaminen con altas concentraciones de bacterias, virus y parásitos, lo cual crea un grave problema de salud pública debido a la posibilidad de propagación enfermedades. Bastando un peligro abstracto, así lo tiene dicho la jurisprudencia del alto tribunal ya citada donde textualmente se narra: "circunstancias que bastan para considerar en peligro la salud humana y el medio ambiente... no hace falta un número determinado de muertes, es inaceptable esperar esto para hablar de un nexo causal, las acciones deben ser tomadas frente al mero peligro, esto es lo que ha dado en denominar Principio Precautorio, que sería lo mismo que decir, que es mucho mejor y más ético, prevenir que curar...." 


\section{La postura defensiva y su desvirtuación}

La posición defensiva utilizada por los responsables del servicio, consistió en aducir que se rompían las bombas encargadas del tratamiento de las aguas servidas lo que había provocado que una boca de inspección expulsara sus líquidos cloacales al arroyo. También aducían actos de vandalismo. Sin embargo esta posición fue criticada por el juzgador reflexionando que estas hipótesis no pueden ser consideradas como caso fortuito debido a la recurrencia de eventos, habiendo transcurrido los mismos sin haber reforzado las instalaciones de seguridad por lo que la Concesionaria no dispuso de los elementos técnicos, que garanticen la operatividad del bombeo, así como tampoco se extremaron las tareas de mitigación necesarias y no se acreditó las cantidades y concentraciones del agente desinfectante aplicado.

Asimismo, el juzgador solicitó a la concesionaria remita su plan de emergencia correspondiente, en el cual debía detallar los pasos a seguir en caso se suscitara este tipo de eventos. Instó a la concesionaria que implemente las acciones preventivas y correctivas necesarias para reducir el impacto ambiental, así como también realizar un trabajo más eficiente ante eventos de esta naturaleza. Este informe fue notificado fehacientemente a los responsables en cédula de notificación para que soluciones los desperfectos en el plazo de cinco (5) días hábiles bajo apercibimiento de sanciones y medidas regulatorias.

No obstante, al advertir que continuaron los volcamientos de líquidos cloacales, sin tomarse muestras de agua en el arroyo para conocer parámetros del desborde, es que se envió nueva cédula de notificación. Por otro costado, en el marco de lo establecido en el contrato de Concesión y las atribuciones conferidas por Ley a este Regulador, habiéndose verificado por Acta de Constatación que continúa el vertido de efluentes crudos a curso superficial, a causa del funcionamiento deficiente de la Estación Elevadora se intimó al Concesionario a instalar en un plazo máximo de veinticuatro horas, el equipamiento que garantice una capacidad de bombeo necesaria para que cese definitivamente el volcamiento de efluente crudo en la posición referida precedentemente.

Dicho ente regulador efectúa un nuevo informe técnico donde concluye que la Concesionaria, desde el punto de vista técnico, no dispuso de los elementos técnicos necesarios para garantizar la operatividad del bombeo, lo que ratifica fehacientemente el incumplimiento o infracción por parte de la Concesionaria. A pesar de la referida intimación a los responsables, continuaron los derrames de aguas contaminantes, así lo evidencia el órgano de control ERSEP. Lo mismo tiene dicho la Dirección de Policía Ambiental dependiente del Ministerio de Agua, Ambiente y Servicio Publico del Gobierno de la Provincia de Córdoba, órgano de fiscalización tal como lo establece el decreto reglamentario № 2149/03 de la ley № 8.973 de adhesión a la ley nacional $n^{\circ} 24.051$ de Residuos Peligrosos, quien 
también efectuó reiteradas actas de constataciones de desbordes de efluentes cloacales, donde se verifica que los efluentes son volcados sobre el arroyo, por lo cual se ratificó el Cese Preventivo y Precautorio dispuesto lo que implica cesar de inmediato todo volcamiento de efluentes cloacales con destino directo al arroyo.

Todo lo narrado permite claramente traslucir la indiferencia de los responsables del resultado contaminante. En efecto, aquéllos crean un peligro al omitir efectuar las tareas de mantenimiento necesarias de las bombas, que excede el riesgo permitido al producirse volcamientos de efluentes contaminantes al Arroyo por el deficiente funcionamiento de la estación de bombeo, lo que conllevó riesgos para la salud de las personas de las localidades afectadas, al contaminarse el arroyo antes aludido. Entonces, se esperaba de sus responsables un plus, en su obrar positivo para extinguir el peligro (o para reducirlo hasta llevarlo otra vez al nivel de lo tolerable) y los destinatarios del servicio, confiaban que así fuera. Era obligación de los mismos de adoptar todas las medidas de aseguramiento para controlar que no se concreten daños, que, evidentemente no adoptaron ya que el riesgo se realizó en el resultado. Los imputados actuaron con indiferencia, aceptando la posibilidad de dicho resultado contaminante, poniendo así en peligro la salud humana y el ambiente.

Al respecto, reconocida doctrina sostiene:

"(...) es claro que la injerencia no puede obligar a la protección de determinados bienes jurídicos frente a toda clase de peligros y la posición de garante sólo puede ser reconocida respecto de aquellas lesiones de bienes jurídicos que representante la realización del peligro creado por la acción previa. Se exige con presupuesto de punibilidad una lesión de un bien jurídico objetivamente imputable a la posición de protección o de evitación del riesgo". (TERRAGNI 2011,46).

También hay que destacarse que los responsables de la empresa Concesionaria no poseen título universitario ni terciario ni capacitación alguna que acredite idoneidad en la materia. En virtud de ello, cita la doctrina imperante que "...no obra dentro del riesgo permitido, pues incrementa el riesgo normal... quien sin tener el oficio de pintor, utiliza los insumos para pintar su vivienda sin leer las instrucciones ni asesorarse, emplea productos tóxicos que afectan a otros habitantes de la casa" (DE LA RUA-TARDITTI2014,308).

\subsection{Las medidas de cese de los efectos del delito}

De todo ello se deriva que la Instrucción fiscal fijó dentro de las condiciones de permanencia en libertad de los imputados, la condición de evitar futuras contaminaciones, conforme el delito atribuido, dentro de las previsiones 
de libertad del Art. 268 del Código procesal penal de la provincia de Córdoba, se intimó a sus responsables a cesar los volcamientos de líquidos cloacales al arroyo, evitando de esta manera nuevas contaminaciones y logrando que pusieran las bombas utilizadas en condiciones óptimas, revirtiendo así la problemática planteada en la actualidad.

\section{Conclusión}

La relación de lo expuesto, muestra que las acciones tomadas por el sistema jurídico, en sus ramas administrativas (Ente Regulador de Servicios Públicos y Dirección de Policía Ambiental), ayudaron significativamente a instaurar la acción del sistema penal, dado que las intimaciones administrativas coadyudaron a clarificar lo que en el caso se sostiene como "incremento del riesgo no permitido" al poner en conocimiento de las personas físicas que cumplían roles estratégicos en la prestataria del servicio, y a la postre acusados e intimados, tomaran efectivo e indubitable conocimiento de la situación de contaminación, siendo la base de la construcción de la hipótesis acusatoria del Ministerio Público Fiscal.

A ello se suman las medidas de cese de los efectos del delito instauradas por la Fiscalía Penal, que incidieron significativamente a solucionar la cuestión problemática presentada al principio por el Intendente de la ciudad afectada y los vecinos de la ciudad. Esto se puso de manifiesto por que pasadas $72 \mathrm{hs}$. de notificados los acusados de que si se reiteraban los volcamientos contaminantes en el mismo curso de agua por las mismas causales investigadas, se entendería como una reiteración de la conducta presuntamente delictiva endilgada y autorizaría a ordenar su detención y traslado a la penitenciaria respectiva; se colocaron los fondos económicos pertinentes y las obras de reparación de las bombas principales y de respaldo, el mantenimiento de la cañería, la desobstrucción inmediata de la misma y el refuerzo del sistema con medidas de cerramiento (colocar tapas a las cámaras de inspección y alambrados), se realizaron con diligencia tal que ocasionó que el funcionamiento del sistema de tratamiento de líquidos cloacales, no sufriera otro desperfecto, y si lo hubo, su reparación fue tan rápida que no se advirtió su volcamiento por ninguna persona habitante de la zona ni órgano de control hasta el día de realización del presente trabajo académico.

Así, se acreditó en los hechos la efectividad del sistema jurídico en su conjunto, a efectos que ante la presunta vulneración del bien jurídico protegido "resguardo del medio ambiente", quede en actos futuros debidamente respetado; $y$ se sepa socialmente que ante la afectación del mismo, el sistema jurídico instaurado es eficaz frente a la aplicación de las sanciones pertinentes; comenzando por los remedios administrativos (multas, etc.) y frente la inobservancia de estos últimos, el sistema represivo del Estado aplicará sus medidas de coerción personal. 
La solución al problema planteado por los peticionantes y la respuesta a la pregunta inicial sobre ¿cómo se gestionan desde el Derecho y el sistema democrático los conflictos relacionados a la degradación del medio ambiente?, en este caso el agua; se responde desde lo examinado en el presente caso empírico, consolidando así la institucionalidad de los órganos públicos pertinentes.

\section{Bibliografía}

CAFFERATTA, Néstor. (2012). Tratado Jurisprudencial y doctrinario - Derecho Ambiental. Buenos Aires, Argentina: La Ley.

CAfFeratA- TARDITTI (2003) Código Procesal Penal de la Provincia de Córdoba Comentado. Córdoba, Argentina: Mediterránea.

DE LA RÚA-TARDITTI. (2014). Derecho Penal. Parte Gral. Buenos Aires, Argentina: Edit.Hammurabi.

FALLOS JURISPRUDENCIALES: Corte Suprema de Justicia de la Nación Argentina, en los autos caratulados: "Montenegro, Jorge Celso s/ denuncia Contaminación Ambiental" de fecha 20/05/2003 y "Zardi, Alejandro W. s/ denuncia infracción ley 24.051". Tribunal Superior de Justicia de la provincia de Córdoba, Sent. 421 del 17/09/2015 "Gabrielli, Jorge Alberto y otros p.ss.aa infracción Ley 24.051 -Recurso de Casación-SAC 2403217-, y Cámara Federal de San Martín en el precedente "Wentzel", "Gabrielli Jorge Alberto, Pancello Edgardo Jorge, Parra Francisco Rafael p.ss.aa. Infracción Ley № 24051-Recurso de Casación-" (Sentencia № 421 de fecha 17-9-2015); la Cámara Federal de San Martín en autos "Constantini, Rodolfo y otros s/averiguación contaminación en Río Reconquista", y la Cámara Federal de General Roca (Rio Negro) en la causa "Peláez.

MAHIQUES, Carlos. (2004). Leyes Penales Especiales. Buenos Aires, Argentina: Fabián J. Di Plácido.

MANDELLI, Adriana. (1995). "Ley de Residuos Peligrosos en Estudios de figuras delictivas" en Daniel P. Carrera (Director). Córdoba, Argentina: Advocatus, Córdoba.

NúÑEZ, Ricardo. (2000). Derecho Penal Parte Especial, 2da. edición actualizada. Córdoba, Argentina: Lerner.

REINALDI, Víctor Félix. (2000). Manual de Derecho Penal. Córdoba. Córdoba, Argentina: Lerner. 
ROSATTI, Horacio. (2011). Tratado de Derecho Constitucional. Buenos Aires, Argentina: Rubinzal- Culzoni.

TERRAGNI, Marco Antonio (2011). Delitos de omisión y posición de garante en Derecho Penal. Buenos Aires, Argentina: Rubizal-Culzoni. 